\title{
CORRUPTION CONCEPT AND ADVANCED ANTI-CORRUPTION SYSTEM IN UKRAINE
}

\section{Muzychenko G. V.}

\section{INTRODUCTION}

Corruption today is fairly considered as one of the main problems of governance at all levels of public life. Corruption is a global phenomenon, which is inherent in all societies, regardless of the level of development and geographical location, but in each country the success of its struggle with its own. This, on the one hand, determines the global nature of the fight against corruption as a socio-legal phenomenon and, on the other hand, intends a certain locality, that means a national scenario of combating corruption in each country which takes into account the level of political and legal consciousness, historical traditions, the economic state of society, etc.

For the last 15 years due to the financial crisis during which the gap between the rich and the rest has increased dramatically, the very rich have game both national and international financial systems, and politicians have received massive contribution to support tax reduction whilst development has effectively stagnated - accusation of corruption have gain come to the fore ${ }^{1}$. It is one of the reasons of political corruption topic actualization in scientific research in Ukraine and most of European counties as well.

Corruption began to spread markedly during the period named «perestroika», when the massive looting of public property, budget money laundering had started with the help of corrupt officials and servants. Since the independence period has started the corruption stimulate the development of the shadow economy and as a worm was eating Ukraine. Mostly the reason of it was a fact that the commercialization of the national economy revealed the urgent need for various types of permits and licenses, which became a peculiar

${ }^{1}$ Muzychenko G., Koliada T., Churkina I. Impact of European Integration Process on the Necessity of Long-Term Budget Planning Introduction in Ukraine. Baltic Journal of Economic Studies, 2017. № 3 (5). P. 330-331. 
commodity with its user-value and price. All attempts to overcome corruption in independent Ukraine were unsuccessful. This has become one of the reasons for the 2014 Revolution of Dignity. P. Poroshenko in his inaugural speech called the first and the main task for Ukraine is to eliminate corruption that absorbed the entire country. The next president of Ukraine Volodymir Zelenskiy also pointed on the corruption as the biggest trouble for our country.

There are three aspects of corruption: political, socio-economic and legal. Proponents of the political aspect define corruption as abuse of authority, official position and administrative capacity in order to receive material repayment. Thus, it causes material and moral damage to the structure of state, the reputation of political power, and the prestige of the country on the international area.

Corruption is one of the functions of corporate governance based on an economic basis, therefore, the economic approach supporters tend to regard it as a form of official abuse, in which a direct or veiled deceptive purposes always insist. Corruption is considered as a complex social and legal phenomenon associated with the bribery of persons who are on the state or public position, with the gaining of additional incomes, benefits and welfares for doing intentional misconducts or being inactive against to the interests of the state and society.

The third approach sees in corruption a purely legal structure as the primary basis for unlawful activity or inactivity. Socio-economic and political factors of corruption are secondary or superstructures over its legal basis.

The fourth approach is also has a right to exist, whose supporters believe that the concept of corruption is complex and includes the political, economic, social, legal and moral spheres of social relations. Corruption is not a specific socially dangerous act, as it is inherent in any component of the crime, but may takes various forms - criminal, administrative, civil, disciplinary and other ${ }^{2}$.

\section{Conceptualisation of corruption and ant-corruption policy}

In order to identify the ways on corruption prevention in modern states, it is necessary to choose a certain model of its development.

2 Музиченко Г. В. Теоретичні аспекти визначення корупції як суспільнополітичного явища. Політикус. 2017. № 3. С. 33-37. 
Scientists (V. Adrianov, B. Baluyev, O. Busol and others) outline several basic models of corruption development, according to the conditional geographical names or customs of a particular country. In particular, the following models are known:

1. Asian (traditional) model. According to this model, not only any service, but even a simple performance of official duties by public person is impossible without appropriate remuneration. Inability or unwillingness to give a proper bribe is perceived in such a society as an attribute of a person's inability to solve his problems. In this case, corruption in the eyes of the masses is not a crime ${ }^{3}$. In such countries an unrelated posts appetites are punished by demonstrative «purges», which are perceived by the public consciousness as the renewal of legality. All this as a result contributes to the stability of the authority vertical because the change of players does not change the rules of the game.

2. The African model is characterized by the fact that the authority in such states is sold to a group of main economic clans that have agreed with each other, and ensure the reliability of their existence by political ways. According to O. Busol, the transition to this model is possible under the following conditions: the political power in the country remains unconsolidated; financial and bureaucratic groups squeeze their existence under the influence of self-preservation instinct and negotiate; an oligarchic consensus is formed between the consolidated financialbureaucratic groups and a part of the political elite ${ }^{4}$. For the country it means the rollback of democracy and the monopolization of the economy.

3. Latin American model. The admissibility of corruption allows the shadow and criminalized sectors of the economy to achieve power that can be compared to the state. Authorities are often drawn into a rigid confrontation with the mafia, which creates a «state in the state». The economic welfare becomes a task which is not only unachievable, but even secondary to other problems. However, the political instability that is characteristic of such countries increases the chances of establishing a dictatorship on the warp of fighting corruption, which in turn leads to the threat of transition to an African model ${ }^{5}$.

${ }^{3}$ Бусол О. Ю. Протидія корупиійній злочинності в Украӥні у сучасний період : монографія. К. : Ін Юре, 2014. С. 37.

${ }^{4}$ The same publication. - P. 38.

${ }^{5}$ The same publication. - P. 43 . 
4. The European model is characterized by a relatively low level of corruption in the almost complete absence of grassroots corruption. This does not exclude the periodic origin of scandals related to the corruption of higher echelons. The low level of corruption in European countries is supported by a set of measures - institutional, organizational, legal, as well as the effective operation of tradition, culture and civil society institutions.

5. Corruption in the post-Soviet countries (corruption under a social contract). In such countries employees who receive salaries from the budget receive inadequate monetary support. At the same time, the state puts a blind eye to receiving remuneration from consumers of administrative services. The danger is that even after a substantial increase in official salaries, the desire and habit of receiving gratitude from the recipients of services, as a rule, does not disappear. That is why the reform of the public system of government is delayed for years.

6. The localized model takes place in societies where most of the population does not give and take bribes. But there are some spheres of economic or political relations where a certain stratum of employees who have the right to sign documents, as well as businessmen who are interested in these decisions, try to find a common language with the help of monetary remuneration ${ }^{6}$.

There are five main models of the combating corruption are described in detail in the scientific papers of Ukrainian and foreign authors:

1. The totalitarian model for combating corruption, which prescribes the comprehensive state control over the officials' behavior and a rigorous response to any deviation from the norms they have made. The disadvantage of this approach is the violation of human rights, since the totalitarianism is fundamentally incompatible with their implementation.

2. The authoritarian model for combating corruption is characterized by selective implementation of responsibility in accordance with the guidance of a manager. This model motivates attempts to get into authorities for the reasons of own security and impunity in the struggle for privileges and full powers, therefore, the processes of power degradation and its gradual tampering are factored into it.

${ }^{6}$ Muzychenko G. Advanced Issues of Legal Adjustment of Anti-corruption Activities in Ukraine. Development of National Law in the context of integration into the European Legal Space. Warszawa. 2018. P. 136. 
3. The oligarchic model of combating corruption assumes that the realization of responsibility is carried out in accordance with the clan approach - on the friend-or-foe principle. Since power is exercised by teams, they defend themselves from responsibility in all available ways, and in relation to strangers they collect juicy details and try to give them a way. Money in such a model is gaining weight, so it can easily be transformed into a criminal one. And the combating corruption itself becomes instrumental and looks as a mean of power struggle between the oligarchic clans. Lack of control generates a massive corruption at the grassroots level of public administration.

4. The liberal anti-corruption model means total irresponsibility, impunity and permissiveness. Such a state is observed during the periods of revolutions, when the new government has not yet taken over management functions or deliberately initiates destructive processes. Such a model is dynamic and sometimes there is a return to the authoritarian model.

5. The legal democratic model is largely embodied in the concept of the rule-of-law state. The realization of such ideas as the consistency of law and morality, the definition of a reasonable hierarchy of values protected by law, the equality of all before the law, the delegation of authority, etc. have the great importance here.

In the combating corruption, it is particularly important to ensure the equality of all before the law as one of the main principle of the rule-oflaw state concept. In particular, this concerns the minimization of legal and factual immunities.

An analysis of the manifestations of corruption in different countries proves that there is a post-Soviet model of combating corruption is reinforced in Ukraine now, although we can talk about certain evidences of the presence of an oligarchic model as well.

\section{Evolution of the Corruption Combating in Ukraine}

Combating and prevention corruption as a socio-economic phenomenon are carried out during all years of independent Ukraine's existence. Until now, unfortunately, it was not possible to overcome it, despite the active work in this area of legislative, executive branches of public authority as well as the law-enforcement bodies.

The historical periods of combating corruption in Ukraine can be systematized in this way: 
The first period - ideological (1991 - first half of 1994). At this time, the formation of the problem of combating corruption and putting it into a topical issue took place. At the same time, there were the processes of increasing corrupt in a supportive environment, that was formed as a result of the unreflective throwing into a market, the fictitious democracy, the total lawlessness, the political mob rule and slogans. Corruption as a socio-economic phenomenon was condemned by the members of the first democratic convocation for Verkhovna Rada of Ukraine (Parliament), such as Vyacheslav Chornovil, Stepan Khmara, Larysa Skoryk, Grigory Omelchenko, Ivan Bilas and others. Also these issues were covered in the speeches by the first president of independent Ukraine, Leonid Kravchuk. However, everything remained at the level of conversations and slogans. But it was also an example of struggle - the ideological one.

Under such favorable conditions, part of Ukrainian officials could not resist the temptation to become wealthy at public cost. The 25 billion UAH (according to current calculations) of state funds were directed to shadow in 1993. In 1992, there were 1182 crimes were carried out in commercial structures, half of them - looting financial resources, and 163 cases of bribery. In the first half of 1994, several bribe-takers were seized, but none of them was convicted.

The second period - a frontal attack on corruption (second half of 1994-1995). After his election, Leonid Kuchma made an important improvement of personal administration in the Ministry of Internal Affairs of Ukraine. As a result, in the second half of 1994, nearly 200 police officers were arraigned on a criminal charge for crime affiliations.

Using the administrative-command methods on corruption prevention and combating it could be a best characteristic for this period. The President of Ukraine signed the Decrees «On corruption prevention and other crimes in the sphere of economy», "On urgent measures to strengthen the fight against crime». The Law of Ukraine «On the Organizational and Legal Foundations of Fighting Organized Crime» was adopted. The challenge was shaken to the shadow authority, with an attempt to end corruption with one decree ${ }^{7}$.

${ }^{7}$ Розвиток національного права в контексті інтеграції в європейський правовий простір : Монографія Інституту Європейської інтеграції. - Розділ VII. Актуальні питання антикорупційної діяльності в Україні. - Варшава, 2018. - С. 138. 
At the end of July 1994, 200 crime scene investigation teams were created from the employees of the Prosecutor General's Office, the Ministry of Internal Affairs, and the Security Service of Ukraine to investigate particularly special economic crimes. However, as it turned out later, there were no reserves for their creation. In many districts of Ukraine was one employed investigator for 10-12 vacant places.

It should be noted that the Presidential decrees were directed to the past. That is, it was about well-known facts of bribery, abuse of official position, mafiosity and lobbying among Ukrainian officials. It was necessary to review all the suspended legal proceedings concerning MPs of different levels, the leadership of the ministries and departments because only among the MPs at that time there were about 500 law breakers.

Unfortunately, the frontal attack on corruption was unsuccessful. For large-scale work there were not enough reserves. On the proposal of the Ministry of Internal Affairs of Ukraine, the Cabinet of Ministers has allocated additional 22 thousand full-time employees. The tendency of the extensive way of combating corruption was determined: the number of law enforcers increased by increasing combating capacity.

An analysis of the combating corruption at this historical period showed that it was impossible to overcome it by individual measures; a comprehensive approach was needed, such as: adoption of sets of normative documents, restructuring of law enforcement agencies as well as the coordination of their activities at the state level. Such measures were distinguished at the following period of time.

The third period - coordination of efforts against corruption (1996-2000). During this period of time, a number of programmatic state normative acts were adopted: Laws of Ukraine «On Combating Corruption», «On the Concept of National Security of Ukraine», «On the National Program for Combating Corruption», «On the unsatisfactory state of implementation of measures to combat crime». They renovated the members of the Coordination Committee for Combating Corruption and Organized Crime under the President of Ukraine, created special units for fighting organized crime in the system of the Ministry of Internal Affairs, the SSU (the «C»department), the State Tax Administration, Tax Police and its special unit - the Anti-Corruption Department. 
On April 24, 1997, the President of Ukraine signed the Decree «On the Establishment of the National Bureau of Investigation of Ukraine». NBIU was planned to be created to strengthen the fighting organized crime in all its manifestations, especially with the corruption of officials and mafia groups. However, the decree was not supported by the Verkhovna Rada of Ukraine and in the end came into force only in 2018.

In 1997, the «clean hands» operation was conducted under the leadership of the President of Ukraine. But corruption has never been overcome. The fact that all these measures had commercial nature and mainly aimed at overcoming the consequences rather than the causes of corruption. Furthermore, the phenomenon of corruption was still not sufficiently studied.

Since 1998 the complexity and application of the methodology of the system approach has been intensified on the corruption prevention. Plans for urgent coordinated actions of state and law enforcement agencies to strengthen the rule of law and order in the country were adopted. A Governmental Working Group was set up to track the shadowing of the economy and develop proposals for its termination. The legislative framework was being improved. The Government prepared a program of economic development of Ukraine. On the basis of it the Government started to combat the corrupt criminal links in state bodies. The legal basis for the combating was the Decree of the President of Ukraine № 367 of April 24, 1998 «On the Concentration of the Combating Corruption for 1998-2005», Resolution of the Cabinet of Ministers of Ukraine of August 3, 2000 № 1050 «On the Plan of Measures to Combat Corruption for the year 2000».

The mechanism of prosecution of civil servants for improper fulfillment of duties wass being improved, which amended the Resolution of the Cabinet of Ministers dated March 4, 1995 № 160 «On Approval of the Procedure for Investigation». In November 1999, Ukraine, together with members of the Council of Europe, signed the Civil Convention against Corruption. In Ukraine, an inter-branch organizational and legal hierarchical deterministic system of combating the shadow economy and corruption was being formed. However, in spite of the taken measures corruption hadn't been overcome.

The fourth period - pseudo-combating corruption (2001-2004). At this time the class disintegration of society is clearly followed. Three classes were formed: very rich, middle class and the poor. Very wealthy 
people have created their capital not always through the accumulation of property at the cost of profits from entrepreneurial activity. There are shadow revenues there, including corruption.

The situation in Ukraine had a dangerous peculiarity, it strangled virtually all segments of the population and was oriented towards maximizing the opportunities for personal enrichment of corruption actors in cost of mistakes made during the reformation of the economy. Criminal elements had already become entrenched and began to occupy leading positions in the economy in order to move in the future to politics. The country had formed a stable corrupt system of power from the President of Ukraine to the head of the village council.

The fifth period - orange (2004-2013). This period of combating corruption is characterized by a number of loud statements at various levels of authority, in particular at the level of the President of Ukraine and the Cabinet of Ministers of Ukraine. There were significant personnel changes both in the center and in the local level. The process of investigation of corruption cases of civil servants was carried out.

The sixth period is modern. Its beginning is associated with the Revolution of Dignity and the election of P. Poroshenko to the President of Ukraine. This period is characterized by considerable attention to the fight against corruption. A new version of the Law of Ukraine «On Preventing Corruption ${ }^{8}$ is adopted, special independent bodies are created - the National Agency on Corruption Prevention (NACP), the National Anti-Corruption Bureau of Ukraine (NABU), the Special Anticorruption Prosecutor's Office (SAP), etc. In addition, the Law of Ukraine «On the Principles of Anticorruption Policy in Ukraine (Anticorruption Strategy) for 2014-2017» was adopted. In accordance with this law all public institutions and subjects of public law have to develop their own anti-corruption activities (programs) and measures for their implementation.

Creation in Ukraine of special law enforcement agencies - the National Agency on Corruption Prevention and the Special AntiCorruption Prosecutor, whose activities are regulated by law, in practice has not yet shown significant progress on combating corruption. On the contrary, their politicization and constant conflicts between themselves and other political institutions are observed. In particular, there is a constant

\footnotetext{
${ }^{8}$ Про запобігання корупиії : Закон України від 14.10.2014 року № 1700-VII.
} 
conflict between NABU, NACP, SAP and the General Prosecutor's Office. The situation was aggravated by the creation in November 2017 of another institution - the National Bureau for Investigations - a special law enforcement agency to review criminal proceedings against crimes committed by high-ranking officials (category A).

\section{Legal aspects of prevention corruption in modern Ukraine}

As the world experience shows, there are three main components of combating corruption are needed for its successful providing:

1) proper (perfect, adapted to the conditions of the country, stable) anti-corruption legislation;

2) its effective use by the relevant state authorities (lawenforcement activities);

3) the political willpower of the government on real combating corruption in all spheres and at all levels of authority ${ }^{9}$.

Each of these components plays a special role on the corruption prevention and combating, but the basic one is still the first one, since combating corruption in a legal democratic state is possible only on a legal basis - this applies to the law enforcement activities, to the expression of political willpower, and to all other measures, which are used in the field of combating corruption. The breaching the law for anticorruption activities is a way to abuse official position, arbitrariness, in which combating corruption will be carried out by the same corrupt means.

Anti-corruption legislation is a conditional term to a certain extent due to the fact that the significant part of the current legislation (constitutional, civil, administrative, economic, etc.) is inherently anticorruption because it is aimed at establishing and regulating social relations, including in the sphere of public administration.

History knows examples when corruption prevention was not limited by the law, but was also carried out by offence methods and means. Thus, the Italian police operated during the reign of B. Mussolini, who strongly opposed the mafia. Police fought the mafia with its own weapons, including the use of violence against persons suspected of being in contact with mafia.

9 Кушнарьов І. В. Політична корупиія: порівняльно-політологічна конџептуалізачія: монографія. Київ: Вид-во «Юридична думка», 2018. С. 135-156. 
In the narrow sense of the word under the anticorruption legislation should be understood those laws and other regulations or their separate rules, which establishes special legislative provisions for the prevention of corruption, determines the responsibility for the commission of corruption offenses, regulates the activities of public authorities or their special units, whose competence is the combating or preventing corruption. In this paper, the anti-corruption legislation is considerated in this sense.

The analysis of current legislation of Ukraine shows that the legal and regulatory framework for combating corruption includes the relevant articles of the Constitution of Ukraine, the laws of Ukraine, resolutions of the Verkhovna Rada of Ukraine, decrees and orders of the President of Ukraine, resolutions and instructions of the Cabinet of Ministers of Ukraine and other normative acts. In total in Ukraine there are about 100 legal act devoted to the solving the problems of combating corruption. Need to say that almost 80 acts passed by the Parliament, the President or the Government of Ukraine contain a direct reference to the term «corruption».

At the same time, the existence of such a number of legal anticorruption acts do not at all indicate that a perfect system of anticorruption legislation has been created in our country. The indicated acts were adopted at different times, by different bodies, for different purposes, and most of them - in the absence of a single scientifically grounded concept of combating corruption.

The Basic Law of our state contains a number of provisions that can be attributed to anti-corruption. In our opinion, the key provision is fixed in Art. 19: "The bodies of public administration and local authorities as well as their officials are obliged to act only on the basis, within the limits of authority and in the manner provided by the Constitution and laws of Ukraine»» ${ }^{10}$. This article in principle defines the framework of lawful conduct of officials of public authorities at state and local levels. It fixes several important points in the anti-corruption meaning: firstly, it determines that the officials can act only in the manner determined by them, and secondly, the grounds, the way of their actions, as well as their responsibilities are determined by law only. Essentially Art. 19 of the Constitution of Ukraine can be defined as the fundamental anticorruption legal norm of our state, because it does not

\footnotetext{
${ }^{10}$ Constitution of Ukraine.
} 
allow any deviations in the activities of officials of these authorities from the behavior determined by law.

A number of other articles of the Constitution of Ukraine specify these provisions or emphasize certain points related to the status of certain officials. Thus, Part 4 of Art. 103 of the Constitution stipulates that «the President of Ukraine may not have another representative mandate, hold a position in state authorities or associations of citizens, as well as engage in other paid or entrepreneurial activities, or to be part of the governing body or supervisory board of an enterprise having the purpose of making profits $\gg{ }^{11}$.

The same kind of restrictions are set for other senior state officials. In accordance with Part 1 of Art. 120 of the Constitution of Ukraine, members of the Cabinet of Ministers of Ukraine, heads of central and local executive bodies shall not have the right to combine their official activities with other work, except for teaching, scientific and creative ones during off-working time, to be part of the governing body or supervisory board of an enterprise having the purpose of making profits. According to Part 2 of Art. 42 of the Constitution of Ukraine, entrepreneurial activity of deputies, officials of state and local authorities is limited by law. Certain limitations are set for judges who can not belong to political parties and trade unions, participate in any political activity, have a representative mandate, hold any other paid positions, perform other paid work, except for scientific, teaching and creative (Part 2 of Article 127 of the Constitution).

Article 78 (Part 2 and 3) of the Constitution of Ukraine establishes restrictions for Members of Parliament of Ukraine. It stipulates: «Deputies can not have another representative mandate or be in the public service. The requirements for the incompatibility of the parliamentary mandate with other activities are established by law» ${ }^{12}$. In case of nonfulfillment of the requirement regarding the incompatibility of the deputy's mandate with other types of activities, the MP gets amotion by a court decision (Part 4 of Article 81 of the Basic Law).

It should be noted that after the entry into force of the Constitution of Ukraine, these constitutional provisions were ignored by many MPs, who at the same time held the mandate of a deputy and the senior positions in

\footnotetext{
${ }^{11}$ Constitution of Ukraine.

${ }^{12}$ The same resourse.
} 
executive bodies, headed entrepreneurial structures, public institutions, banks, ect. Attempts to bring the status of parliamentarians in line with the Constitution, in spite of the legal certainty of the provision, succeeded in some cases only and after longstanding legal proceedings.

The Constitution of Ukraine contains a number of other provisions that can be regarded as anti-corruption. In particular, it concerns the requirements for the declaration of income and property (Article 67), the procedure for using funds from the state budget of Ukraine (Article 95).

The relevant general anti-corruption provisions that apply to certain requirements and restrictions related to the status of an official include the laws of Ukraine «On the Status of Member of the Parliament of Ukraine» (Article 3), «On the High Council of Justice» (Article 3), «On the National Bank of Ukraine»(Article 65), «On the Constitutional Court of Ukraine» (Article 16), «On the Prosecutor's Office» (Article 46), «On the National Police»(Article 18), «On Local State Administrations» (Article 12) and a number of other laws.

The main regulatory act, which focuses on special preventive anticorruption provisions, is the Law of Ukraine «On Prevention of Corruption» (2014). The existence of this Law refers Ukraine to the few countries established in the former Soviet Union, in which there is a special anti-corruption law, which provides for special restrictions for persons authorized to perform the functions of the state, provides for other requirements to them, defines signs of corruption offenses and establishes responsibility for their committing (the law of direct action).

The undeniable positive moment of this Law is that it contains the ethical and legal foundations of moral and lawful conduct of public servants and other persons authorized to perform the state functions. Its prophylactic character is determined by two main points: firstly, it provides for certain restrictions for persons authorized to perform state functions, preventing the coming of corruption relations into existence; secondly, it establishes administrative and disciplinary responsibility for violating these restrictions and committing the corrupt acts determined by it, and it serves as a preventive measure for more dangerous corruption manifestations, primarily criminal.

The main purpose of all prohibitions and restrictions is to prevent the use of persons authorized to perform the functions of the state, their official powers and other opportunities provided to them by official status, for unlawful personal enrichment, which may be carried out by 
engaging in entrepreneurial activity, unlawful promotion or creation of artificial obstacles for the implementation of such activities by other persons. All these «compatibilities», «promotions», «refusals» and others from the officials with authority are nothing more than a favorable ground for all kinds of official misconduct.

The law also provides measures for financial control, first of all, obliges public servants to declare their property status and incomes. It should be emphasized that the fixation of the property status and income of citizens through declaring - is widely used instrument to control the income of each citizen, their source and lawfulness. At present, Ukraine does not legally foresee the mandatory to declare property and incomes for all Ukrainian citizens. Although in the Constitution of Ukraine (Article 67) it is written: «All citizens annually submit to the tax offices at their place of residence the declaration of their property status and income for the last year in accordance with the procedure established by law» [9]. Analysis of the current legislation shows that at the legislative level the issue of declaration is regulated only for certain categories of citizens, in particular, public servants, other persons authorized to perform functions of the state, persons who are applying for these positions as well.

The given legislative base on declaration of incomes and property does not solve the problem of financial control over incomes and expenditures of public servants. In circumstances when the country does not establish a general declaration of income and property for all citizens, it remains possibility for public servants to conceal their incomes and property.

The current legislation of Ukraine, depending on the nature of the offense, establishes criminal, administrative and disciplinary liability for corruption offenses. Criminal liability for corruption manifests itself in the cases provided for by the current Criminal Code of Ukraine (CCU). The most serious among them is illegal enrichment, committed by an official who is particularly responsible (Article 367.3 of the CCU), for which the current Criminal Code of Ukraine may be sentenced to imprisonment for a term of five to ten years with deprivation of liberty to occupy certain positions or engage in certain activities for up to three years with the confiscation of property.

The analysis of sanctions of criminal law, which provides for liability for corruption manifestations of a criminal nature, shows that the 
current criminal law establishes a fairly strict liability for such an act. In particular, it concerns sanctions on bribery that are unreasonably overestimated. In their definition, they came from the fact that the more severe the sanction, the more effective it is in terms of performing the functions of punishment. However, this is not quite as evidenced by the jurisprudence. Courts to ensure the implementation of the general principles of punishment are forced to go beyond the sanctions and impose a softer punishment than prescribed by law.

Administrative liability comes for the commission of all offenses established by the Law of Ukraine «On the Prevention of Corruption» (2014). The peculiarity of the sanctions of the norms of this law is that both an administrative and the disciplinary liabilities are provided for, and also establish for other perpetrators of acts of corruption other negative consequences of a legal nature.

Section 13-A of the Code of Ukraine on Administrative Offenses clearly regulates administrative liability for the commission of corruption offenses. The most severe punishment is for the violation of the person's restrictions on engaging in other paid activities like an entrepreneurship in the form of imposing a fine from 300 to 500, and in the case of a repeated violation - up to 800 non-taxable minimum incomes of citizens with the confiscation of income from entrepreneurial activity or remuneration from work part-time with a deprivation of the right to occupy certain positions for one year.

\section{CONCLUSIONS}

The analysis of the legal regulation of anti-corruption activities in Ukraine proves that the main preconditions for the origin and spread of corruption in Ukrainian society are: political and economic instability in the country; the discrepancy of the income of most of the population with a real cost of living; imperfection of the system of public administration; delay in creating an effective system of work with personnel at all levels; lack of transparency, publicity in the activities of public authorities, lack of effective levers of public influence; low level of legal culture of the population, etc.

Corruption in every country has a certain national development model (Asian, African, post-Soviet, European, etc.), on the basis of which the national system of prevention and combating corruption is developed. The model of post-Soviet countries is now firmly established in Ukraine. 
This model includes some elements of the oligarchic model on combating corruption.

Ukraine has created a sufficient legal framework for effective prevention and combating corruption with a whole range of criminal, administrative, civil, legal, disciplinary and other measures. There have been some changes in the institutional provision of anti-corruption activities in Ukraine. In particular, the National Agency on Corruption Prevention (NACP), the National Anti-Corruption Bureau of Ukraine (NABU), the Special Anti-corruption Prosecutor's Office (SAP) and the State Investigation Bureau have already been created. In turn, the creation of the Anticorruption Court of Ukraine.

The world experience in combating corruption reveals that no legislative or administrative measures can be effective if the society does not have the political willpower for that. Therefore, in order to further improve the anti-corruption legislation in Ukraine, it is advisable to take the following measures:

- to cancel the practice of «blind» copying of the norms of foreign legislation, facile and slick application of the provisions and recommendations of international acts on combating corruption without taking into account historical, socio-economic, cultural and other peculiarities of Ukraine, the mentality of the population, forecasting the possible consequences of the introduction of those or other legal norms;

- to create an effective system of training, professional training and advanced training in the field of prevention and combating corruption for all subjects of public law in Ukraine;

- to complete the process of institutional provision of anticorruption activities in Ukraine through the creation of the Anticorruption Court of Ukraine;

- to ensure cooperation between the main institutions of anticorruption activity in Ukraine and so on.

\section{SUMMARY}

The current status of counteraction and prevention of corruption in Ukraine at the level of legislation and institutional support of anticorruption activity are studied. It is noted that during the years of independence in Ukraine, corruption has become one of the threats of national security and democratic governance, and the fight against it is recognized as one of the priorities of the national authorities. 
The anti-corruption essence of legislation is mainly to prevent a conflict of interests (personal and official), to define the legal framework of lawful and ethical behavior of a person authorized to perform public functions, to make corruption offenses a disadvantageous and risky thing, and eventually to achieve that person honestly and conscientiously fulfilled his official duties. Secondly, we need it for clear identification of the corruption crimes characteristics, to provide adequate measures of responsibility for their commission, to regulate properly the activities of public authorities and their separate units that directly prevent corruption.

For the present, the anti-corruption legislation of Ukraine is presented by the Law of Ukraine «On Prevention of Corruption», as well as relevant articles of the Criminal Code of Ukraine and the Code of Ukraine on Administrative Offenses. They are up to the requirements of the European legal field in form, but there are some problems with their practical application, which is mainly due to the lack of political willpower of legislators.

\section{REFERENCES}

1. Музиченко Г. В. Теоретичні аспекти визначення корупції як суспільно-політичного явища. Політикус. 2017. № 3. С. 33-37.

2. Бусол О. Ю. Протидія корупційній злочинності в Украӥні у сучасний період : монографія. К. : Ін Юре, 2014. 564 с.

3. Конституиія України від 28.06.1996 № 254к/96-BP. URL: https://zakon.rada.gov.ua/laws/show/254к/96-вр

4. Кушнарьов І. В. Політична корупиія: порівняльно-політологічна кониептуалізачія: монографія. Київ: Вид-во «Юридична думка», 2018. 408 с.

5. Про запобігання корупиіï: Закон України від 14.10.2014 року № 1700-VII. URL: http://zakon2.rada.gov.ua/laws/show/1700-18

6. Розвиток національного права в контексті інтеграції в європейський правовий простір : Монографія Інституту Європейської інтеграції. - Розділ VII. Актуальні питання антикорупційної діяльності в Україні. - Варшава, 2018. - С. 135-153.

7. Фоміна М. В. Корупція : сутність, причини, методологія оцінки. Академічний огляд Донецького нац. ун-ту економіки $i$ торгівлі ім. М. Туган-Барановського. 2012. № 2 (37). С. 36-44. 
8. Heywood P., Navot D. New trends in the Conceptualisation of Political Corruption. URL: https://ecpr.eu/Events/PanelDetails.aspx? PanelID=7675\&EventID=121

9. Muzychenko G. Advanced Issues of Legal Adjustment of Anticorruption Activities in Ukraine. Development of National Law in the context of integration into the European Legal Space. Warszawa. 2018. P. 133-151.

10. Muzychenko G., Koliada T., Churkina I. Impact of European Integration Process on the Necessity of Long-Term Budget Planning Introduction in Ukraine. Baltic Journal of Economic Studies, 2017. № 3 (5). 329-333.

\section{Information about the author:} Muzychenko G. V. Doctor of Political Sciences, Professor of the Department of Political Sciences and Law, State institution «Southern National Pedagogical University named after K. D. Ushinsky» 26, Starofrankivska str., Odesa, 65000, Ukraine 